\title{
THE EFFECT OF BACK SCATTER RADIATION ON SURFACE DOSE AS MEASURED BY TLDs
}

$B N L--47040$

R.Boguslavsky ${ }^{\dagger}$, N. Gmür, w. Thomlinson

DE92 007184

National Synchrotron Light Source

Brookhaven National Laboratory

Upton, New York 11973

December 1991

Research Supported by the OFFICE OF BASIC ENERGY SCIENCES

\section{NATIONAL SYNCHROTRON LIGHT SOURCE BROOKHAVEN NATIONAL LABORATORY Associated Universities, Inc.}

\section{U.S. DEPARTMENT OF ENERGY WASHINGTON, D.C.}

\section{DISCLAIMER}

\footnotetext{
This report was prepared as an account of work sponsoned by an agency of the United States Government. Neitiver the United States Government nor any agency thereof, nor any of their employess, makes any warranty, express or ir plied, or assumes any legal liability or responsibility for the accuracy, compieteness, of usefulness of any information, apparatus, product, or processis disclosed. or represent:i that it: wise would not infringe privately owned rights. Reference herem lo any specific commercal product, prosess, or service by trade name, trademark, manuficturer, or atherwise foes not necessarily constitute or imply its endorsement. recom.

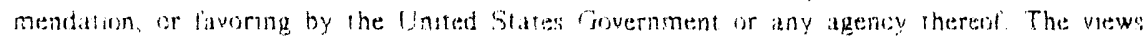
and opmons of authors expressed herein do not necessiariv state or reflest those of the Intest ilates fovernment or any agency ihereof
}

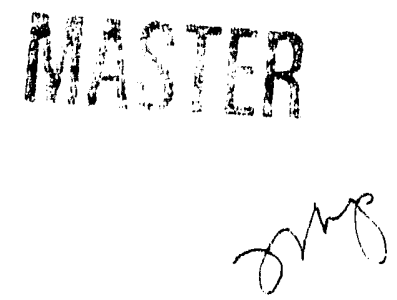




\section{INTRODUCTION}

A group of scientists at HASYLAB in Germany are doing an Angiography project in parallel with a group of scientists at the Brookhaven National Laboratory, National Synchrotron Light Source [1,2]. In order to determine the $\mathrm{X}$-ray dose to a patient, the German group places lithium flioride thermoluminescent dosimeters (TLD) on the front (upstream) surface of their patient. They found that the TLD dose was higher than the dose calculated from an ionization chamber. An ionization chamber is a device that counts the number of photons when a beam of synchrotron radiation passes through. Dr. WolfRainer Dix of HASYLAB found that there is a difference of about $15 \%$ between dose data from TLDs put on a water tub and TLDs in the air. The goal of the experiment we did was to understand and maybe match the dose numbers Dix obtained.

\section{SYNCHROTRON RADIATION}

A storage ring dedicated to the production of synchrotron radiation is structured around a ring-shaped vacuum chamber through which bunches of electrons circulate at $99.999 \%$ of the speed of light. Bending magnets force the electron bunches to curve, causing the particles to lose energy ini the form of synchrotron radiation. A bending magnet typically establishes a uniform magnetic field that is at right angles to the direction in which the electrons are moving. Such a field bends the path of electrons. Whenever a charged particle is accelerated or decelerated, it gives off electromagnetic radiation [3]. The storage ring consists of curved and straight sections. Another magnetic device, the wiggler, may be placed on a linear part of the ring. The wiggler increases the "brightiness" of radiation. At NSLS the high field wiggler extends the synchrotron radiation spectrum to higher energies. It also increases the intensity of the synchrotron radiation. The reason scientists who work on Angiography imaging projects use the wiggler is because they work with $X$-ray energies of $33 \mathrm{keV}$, and the intensity at $33 \mathrm{keV}$ producet by the wiggler is much higher than that produced by bending magnets.

\section{CORONARY ANGIOGRAPHY}

Coronary angiography is the $x$-ray imaging of coronary arteries [3]. Conventional angiography is a risky procedure. It involves the injection of an iodine contrast agent directly into a coronary artery through a plastic catheter which has been threaded to the heart through the femoral (leg) artery. In an attempt to reduce the risk, a procedure known as transvenous coronary angiography was developed by Stanford University physicians and physicisss [4]. This technique is now being studied at the National Syncturotron Light Source and involves catherization of a brachial (arm) vein, a much safer procedure. The contrast agent is injected inw the superior vena cava and travels to the coronary arteries at the beginning of the aorta. By now the contrast agent has diluted 20-30 fold. The wiggler on the NSLS synchrotron storage ring is the very powerful source of $x$-rays used for the imaging [5]. A patient is scanned with two monochromatic beams creating two simultaneous images. One beam is just below the absorption edge of iodine and one just above it. The k-absorption edge of iodine is $33.169 \mathrm{keV}$. By subtracting the low energy image from the high energy image we can see the contrast between blood vessels that contain iodire and the rest of the body tissue. Since this procedure uses $x$-rays, it is very important to know the radiation dose given to a patient during imaging.

\section{HYPOTHESIS}

To understand and explain the results Dr. Dix obtained we came up with the hypothesis that when a beam of synchrotron radiation enters a patient's body some radiation is scattered back and that back scattering radiation increases the dose measured by TLDs on the surface of the skin.

$$
-1-
$$




\section{EXPERIMENTAL SETUP}

The experiment was carried out on the X17B2 Angiography beamline (see Figure 1) [2,5]. To set up and do the experiment that would show that there is back scattering of radiation we decided to measure the surface dose to TLDs with and without any water absorbers behind it To do this first step in our experiment we took a piece of cardbnard, cut out a window in it and put four TLDs in the window on a piece of tape, and scanned them on a patient chair twice through synchrotron radiation at an energy of $33 \mathrm{keV}$. We measured the dose, then we changed TLDs and added $21 \mathrm{~mm}$ of water absorbers. This procedure was repeated 6 times such that at the end of the experiment we had surface dose measurments of radiation with $0 \mathrm{~mm}, 21 \mathrm{~mm}, 42 \mathrm{~mm}, 63 \mathrm{~mm}, 84 \mathrm{~mm}, 105 \mathrm{~mm}$ and $126 \mathrm{~mm}$ of water absorbers behind the cardboard with TLDs (see Figure 2).

\section{RESULTS}

The TLDs were analysed for dose by the Personnel Monitoring Group at the BNL Safety and Environmental Protection Division. Based on the conditions of the ring and the beamline we calculated the dose for each step of our experiment in rads per chair transit per milliamp ring current (see Table 1). After doing all the calculations the results were ploted on a graph (see Figure 3).

\section{DISCUSSION OF THE RESULTS}

The experiment confirmed that there is back scatter of radiation. The surface dose increases due to back scatter as water absorber thickness increases up to $42 \mathrm{~mm}$. Further increase of water absorber thickness does not have any effect on a surface dose (see Figure 3). Radiation back scatters from all water absorbers but it does not influence the surface dose fiurther than $42 \mathrm{~mm}$ because it gets reabsorbed. While point 6 on Figure 3 appears out of line, the: BNL Personnel Monitoring Group has informed us that within any single batch of TLDs exposed to the same amount of radiation the dose may vary by up to $5-10 \%$. The data for thicknesses $\geq 42 \mathrm{~mm}$ are constant within that error level.

\section{CONCLUSION}

In this experiment we tried to understand the results of Dr. Wolf-Rainer Dix of HASYLAB. Both measurments support our hypothesis of backscattering. We found a $43.1 \%$ increase in dose between TLDs on $42 \mathrm{~mm}$ of water absorbers and TLDs in the air. This result is qualitatively in agreement with the results of the German scientists who obtained abou $15 \%$. Smallwood and Chapman [6] are atempting to model this back scattering effect mathematically. 


\section{BIBLIOGRAPHY}

[1] W.-R. Dix, K. Engelke, G. Heintze, H. Heuer, W. Graeff, W. Kupper, M. Lohmann, I. Makin, T. Moect:' R. Reumann, and K.-H. Stellmaschek, SPIE 1090 (1989) 282.

[2] W. Thomlinson, N. Gmür, D. Chapman, R. Garret, N. Lazarz, H. Moulin, A. C. Thompson, H. D. Zeman, G. S. Brown, J. Morrison, P. Reiser, V. Padmanabhan, L. Ong, S. Green, J. Giacomini, H. Gordon and E. Rubenstein, Proc. of 4th Int. Conf. on Synch. Rad. Instr., Chester, UK, July 1991.

[3] H. Winick. 1987. Synchrotron Radiation. Scientific American Vol. 257, No. 5: 88-99.

[4] E. Rubenstein, E.B. Hughes, L.E. Campbell, R. Hofstadter, R.L. Kirk, T.J. Krolicki, J.P. Stone, S. Wilson, H.D. Zeman, W.R. Brody, A. Macovski, and A.C. Thompson, SPIE 314 (1981) 42

[5] W. Thomlinson, D. Chapman, N. Gmür, and N. Lazarz, Nucl. Instr. and Meth. A266 (1988) 226.

[6] S. Smallwood and L.D. Chaprnan. (manuscript in preparation) A Program to Estimate the Contribution to X-ray Dose from Compton Scatter in the Surrounding Media. National Synchrotron Light Source, Brookhaven National Laboratory, Upton, NY. BNL Informal Report.

†Present Address: Wr.udville Road, P.O. Box 677, Shoreham, NY 11786 


\section{TABLES}

Table 1. TLD doses from backscatter dosimetry experiment

- superconducting wiggier field $=4.4$ Tesla

- $x$-ray energies $(2)=$ above and below $33.169 \mathrm{keV}$ iodine $\mathrm{k}$-edge

- $x$-ray beams $(2)=0.5 \mathrm{~mm}$ high $\times 126 \mathrm{~mm}$ wile

- patient chair speed $=12 \mathrm{~cm} / \mathrm{sec}$

- TLD type $=$ lithium fluoride TLD-700 squares, $3.1 \mathrm{~mm} \times 3.1 \mathrm{~mm} \times 0.89 \mathrm{~mm}$ (Harshaw/Filtrol, Solon, Ohio), each held in plastic shrink-wrap tubing.

- absorbers $=$ distilled water held in plexiglass tanks, $250 \mathrm{~mm} \times 160 \mathrm{~mm} \times$ variable depth.

\begin{tabular}{|c|c|c|c|c|c|c|}
\hline Run \# & $\begin{array}{l}\text { Ring } \\
\text { Current } \\
\text { (mA) }\end{array}$ & $\begin{array}{l}\text { Chair } \\
\text { Transits } \\
\text { Through } \\
\text { Beams }\end{array}$ & $\begin{array}{c}\text { Total } \\
\text { Absorber } \\
\text { Thickness } \\
\text { (mm) }\end{array}$ & $\begin{array}{c}\text { TLD } \\
\text { Numbers } \\
\text { and } \\
\text { Positions }\end{array}$ & $\begin{array}{l}\text { TLD } \\
\text { Doses } \\
\text { (mR) }\end{array}$ & $\begin{array}{c}\text { Normalized } \\
\text { TLD Doses } \\
\text { (Rads/Transit/mA) }\end{array}$ \\
\hline 1 & 167.9 & 2 & 0 & $\begin{array}{l}A=39 \\
B=32 \\
C=43 \\
D=24 \\
\text { Mean }\end{array}$ & $\begin{array}{l}1478.9 \\
1564.4 \\
1400.7 \\
1453.5 \\
1474.4\end{array}$ & $4.39 \mathrm{E}-3$ \\
\hline 2 & 166.8 & 2 & 21 & $\begin{array}{l}A=49 \\
B=26 \\
C=47 \\
D=30 \\
\text { Mean }\end{array}$ & $\begin{array}{l}1960.7 \\
1788.9 \\
1956.0 \\
1737.3 \\
1860.7\end{array}$ & $5.58 \mathrm{E}-3$ \\
\hline 3 & 155.5 & 2 & 42 & $\begin{array}{l}A=09 \\
B=42 \\
C=50 \\
D=08 \\
\text { Mean }\end{array}$ & $\begin{array}{l}1974.6 \\
2329.1 \\
2008.2 \\
2000.8 \\
\mathbf{2 0 7 8 . 2}\end{array}$ & $6.28 \mathrm{E}-3$ \\
\hline 4 & 165.3 & 2 & 63 & $\begin{array}{l}A=16 \\
B=52 \\
C=36 \\
D=41 \\
\text { Mean }\end{array}$ & $\begin{array}{l}2002.1 \\
2163.0 \\
1966.5 \\
2229.9 \\
2090.4\end{array}$ & $6.32 \mathrm{E}-3$ \\
\hline 5 & 165.1 & 2 & 84 & $\begin{array}{l}A=22 \\
B=38 \\
C=20 \\
D=56 \\
\text { Mean }\end{array}$ & $\begin{array}{l}2165.4 \\
1971.5 \\
1903.6 \\
2152.4 \\
2048 . ?\end{array}$ & $6.20 \mathrm{E}-3$ \\
\hline 6 & 165.0 & 2 & 105 & $\begin{array}{l}A=45 \\
B=46 \\
C=13 \\
D=55 \\
\text { Mean }\end{array}$ & $\begin{array}{l}1690.1 \\
1925.2 \\
2028.7 \\
2034.1 \\
1919.5\end{array}$ & $5.82 \mathrm{E}-3$ \\
\hline 7 & 164.7 & 2 & 126 & $\begin{array}{l}A=28 \\
B=53 \\
C=10 \\
D=21 \\
\text { Mean }\end{array}$ & $\begin{array}{l}2019.7 \\
1973.7 \\
2223.7 \\
2261.4 \\
2119.6\end{array}$ & $6.43 E-3$ \\
\hline
\end{tabular}




\section{FTGURE CAPTIONS}

1. Diagram of the NSLS angiography beamline.

2. Diagram showing the details of experimental set-up: A) TLDs; B) cardboard holder; C) water absorbers.

3. Graph of TLD-700 dose vs. water absorber thickness.

$-5-$ 


$$
\text { - }
$$




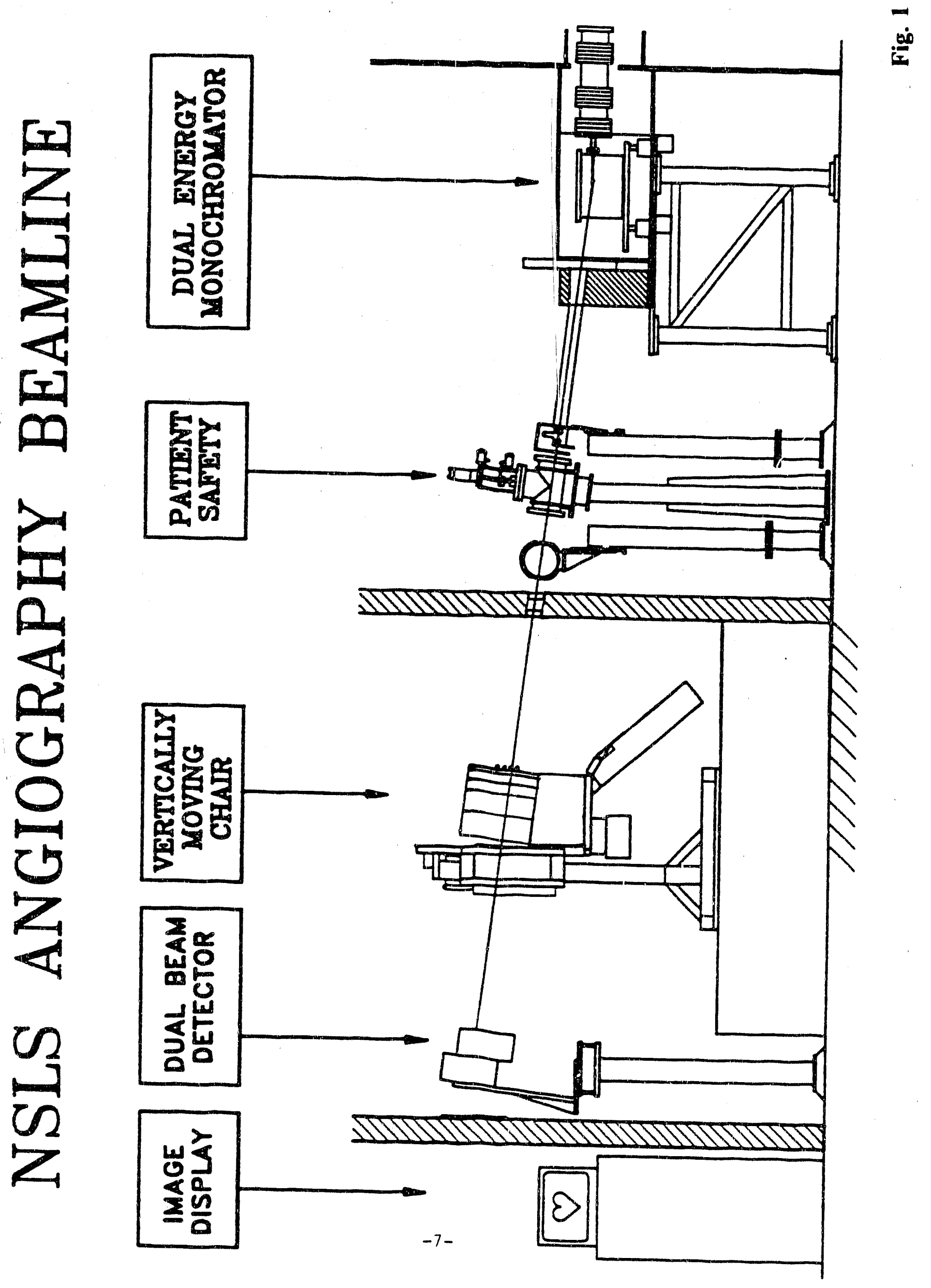


$\ddot{z}$

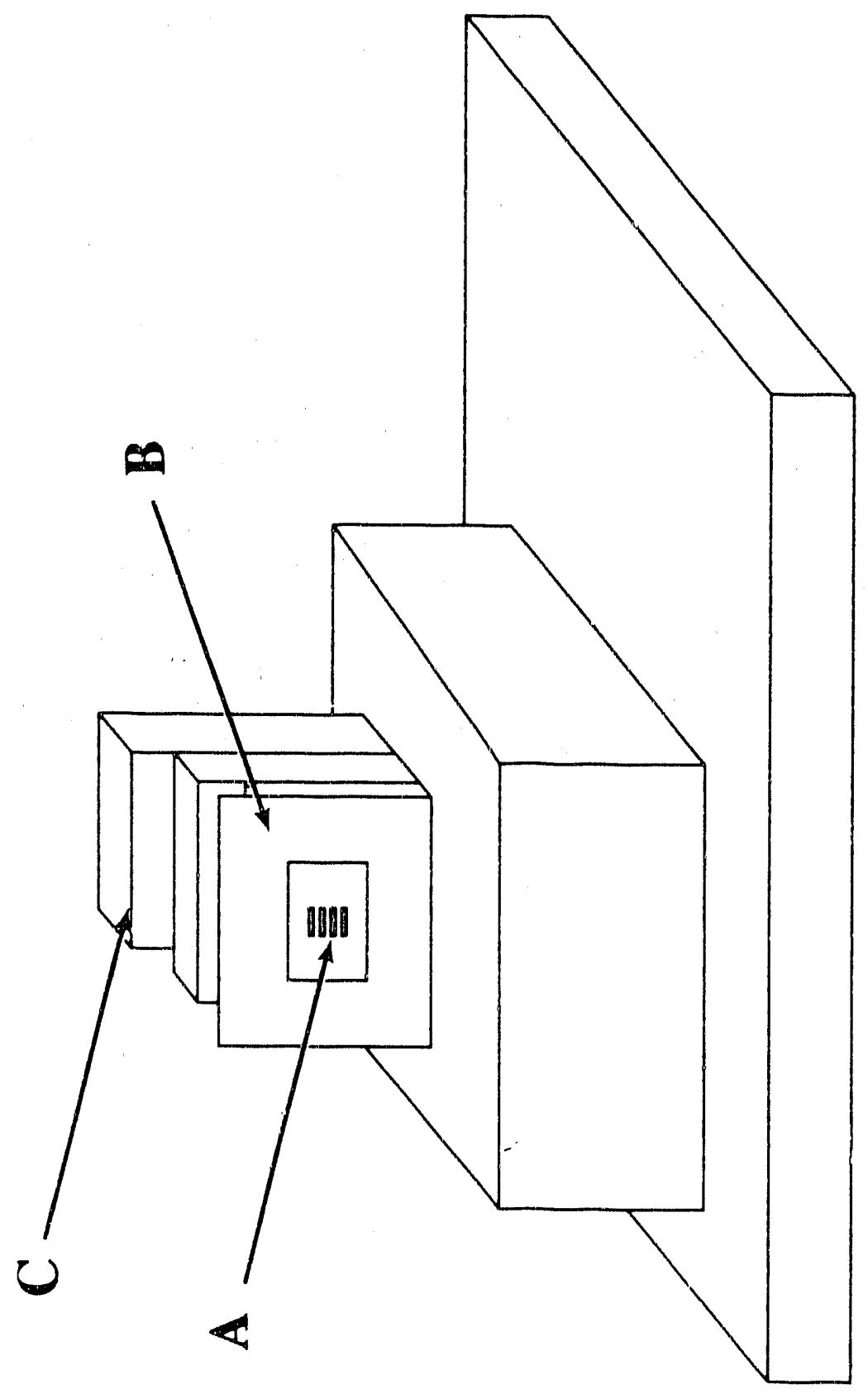




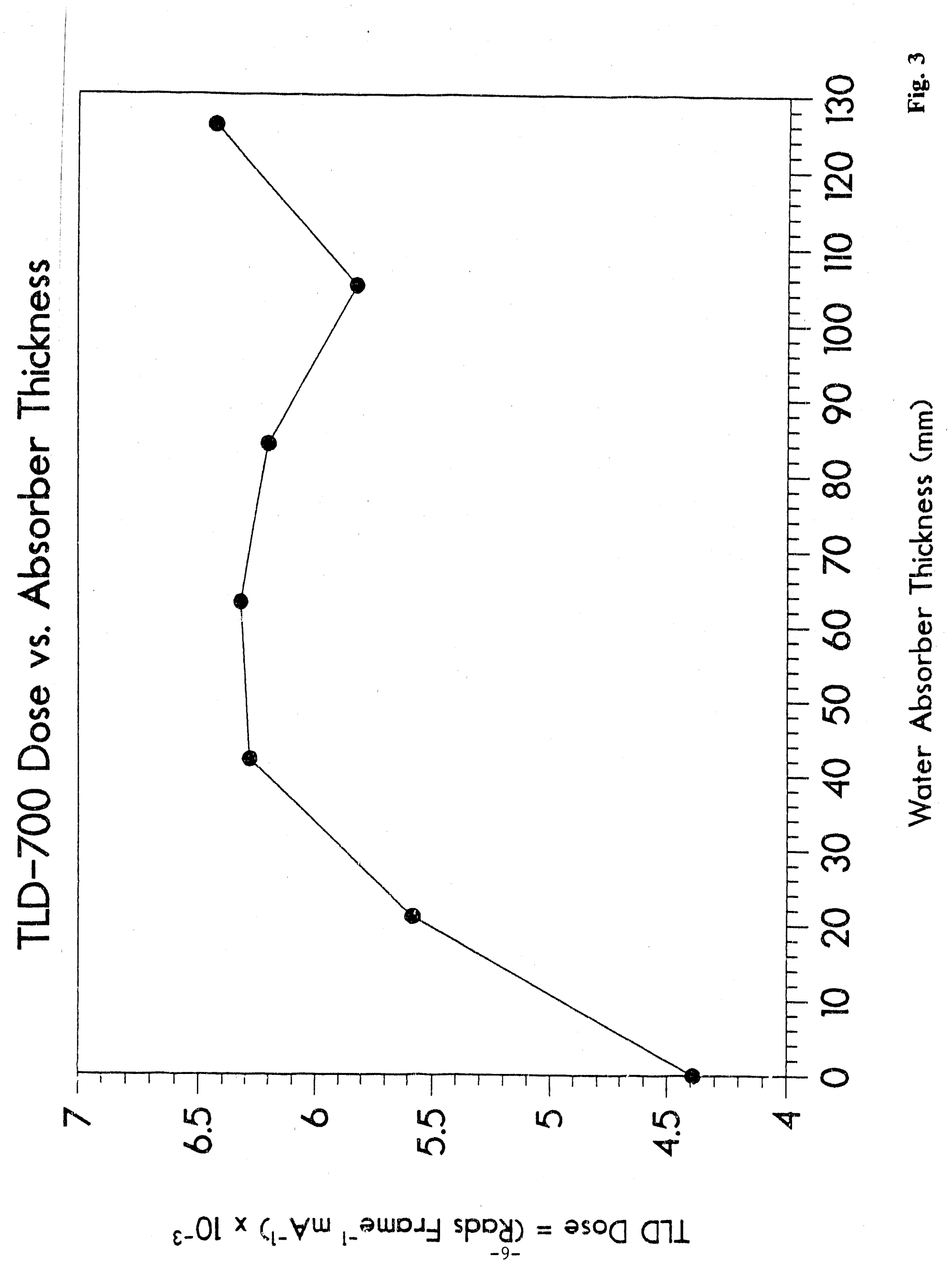



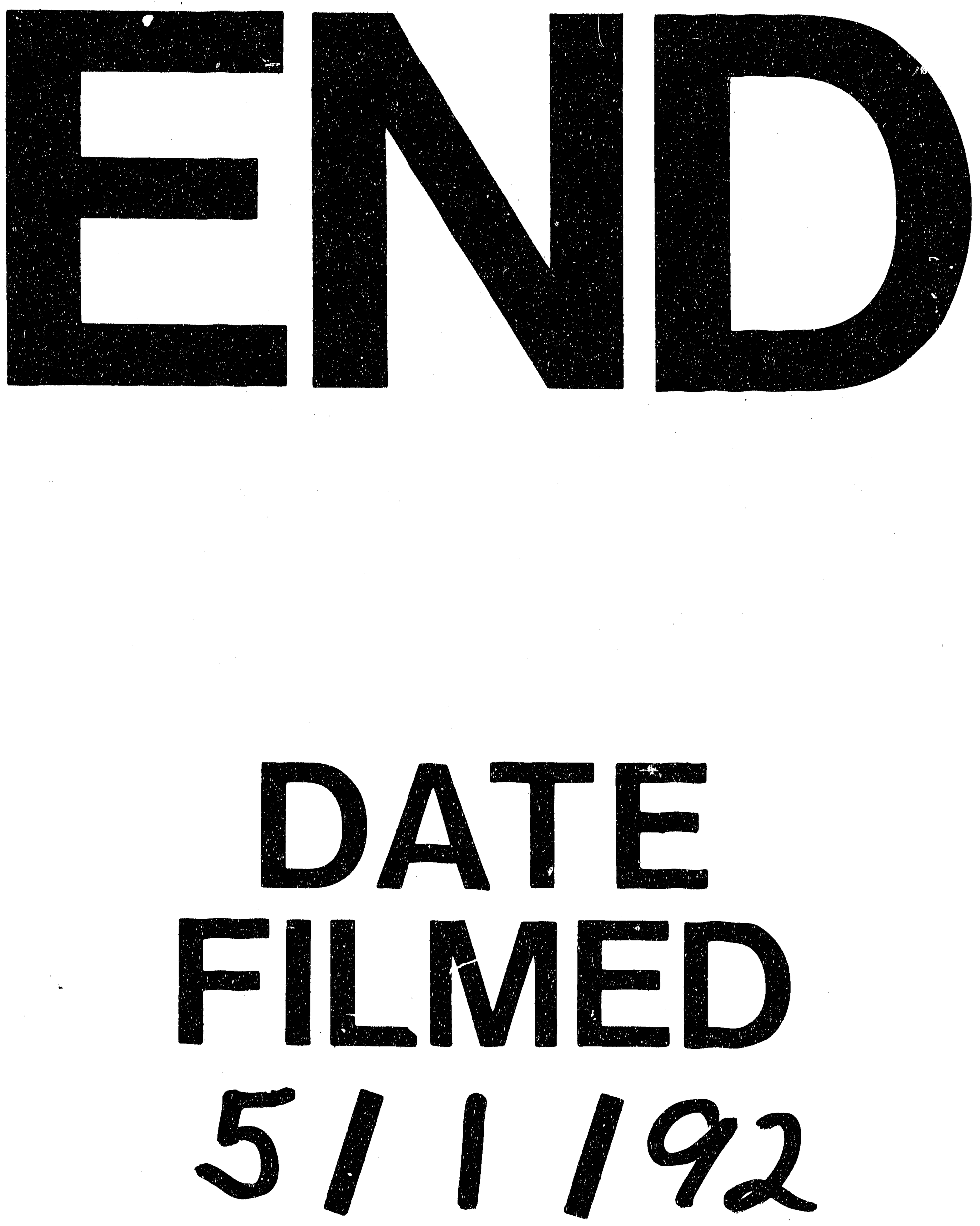
